\title{
thelomj
}

Feature Christmas 2008: Food and Drink

\section{Billy Bunter and the obesogenic environment}

BMJ 2008; 337 doi: http://dx.doi.org/10.1136/bmj.a2877 (Published 16 December 2008) Cite this as: BMJ 2008;337:a2877

\section{Mark Petticrew, professor}

${ }^{1}$ Public and Environmental Health Research Unit, London School of Hygiene and Tropical Medicine, London WC1E 7HT Correspondence to: mark.petticrew@Ishtm.ac.uk

Cripes, said Bunter, what will the government do next? Mark Petticrew investigates

"Come in!" barked Mr Quelch, form master of the Lower Fourth, in response to a tentative knocking at his study door. He set aside the history of Greyfriars School on which he had been working and peered over the top of his glasses at the rotund form that sidled into his office.

"Ah . . Bunter. What do you want? This had better be important. And if it isn't ..." He flexed his cane meaningfully, glancing in the direction of Bunter's ample rump in a manner fortunately now absent from stories about bespectacled public schoolboys.

Bunter blinked owlishly behind his thick, pre-NHS horn-rimmed glasses.

"Sir!" he squeaked. "It's the school vending machine. There's something wrong with it."

"Wrong, Bunter? What could possibly be wrong with it?"

"Sir," went on Bunter nervously "You know how it usually dispenses Mrs Bloater's Carbonated Cordials? Well, the bottles now only seem to contain this colourless, odourless fluid. .."

He waggled a plastic bottle at Quelch. "I think she's trying to pull a fast one, Quelchy—I mean, SIR" he corrected himself quickly. "I think this is. .." he leant forward conspiratorially ". . . WATER!"

"Of course it's water, Bunter you dolt!" exploded Quelch. "Junk food has been banned in schools since $2006 ! " 1$

Bunter blinked, his mouth a surprised "O."

"Anything else, Bunter"?

The Fat Owl of the Remove nodded. “Er . . yes, Sir. We don't like this new healthier food regimeHarry Wharton, Coker, and some of the other chaps would like to you bring back Mrs Miggins' Whopping Offal Pies, and her 'Big Yankee' Burgers." 
"No, Bunter."

"But why, Sir?"

"Well, Bunter, l'd like to tell you what was in those burgers, but that will have to wait until we discuss the bovine reproductive system in biology classes. Let's just call it 'non-lean meat' for now."

Bunter's eyes grew moist as the implications sank in. He looked down at his ample stomach. "Goodbye, old chum," he whispered sadly. Then his face brightened. "Still, there's always the tuck shop! In case, I mean, a chap was a bit peckish ... starving, actually. And I've got my hamper from home every term . . . and some of the chaps are getting emergency deliveries of chips through the school railings."

"Listen, boy. It'll do you good to lose a bit of weight. A third of children are now overweight or obese, and, as the so called 'Fat Owl of the Remove' you're definitely one of them-more than one, probably. 2 What's your waist:hip ratio?"

"I don't know sir. At my last school medical the tape measure didn't reach all the way round."3

"I think that means you're fat, Bunter."

"Ooh, Sir, you can't call me that!" admonished Bunter. "The Department of Health doesn't allow that sort of beastly language to schoolchildren anymore. You have to say 'overweight'."4

"Nonsense, boy—run along and get some exercise."

"But, sir, the PE class has been cancelled-Greyfriars sold the playing fields to ObeseCo to build a new hypermarket. So it's not my fault I'm a little ... er . . Rubenesque." And with that Bunter scuttled out.

Quelch gazed out over Greyfriars' grounds and wondered whether the school really was contributing to Bunter's weight problem. Was Greyfriars an obesogenic environment?5 And if so, then why was Bunter so much fatter than his chums? Was it related to his postal order from home, perhaps? After all, smoking in schoolchildren is related to pocket money. 6 Perhaps it was the same for unhealthy eating. And what was the government doing about all this anyway? He glanced through the recent "Healthy Weight Healthy Lives" strategy,2 and noted that the Health Minister "plans to introduce compulsory cooking for all 11 to 14 year olds." That's a bit drastic, thought Quelch—then again, he reflected, some of them probably deserved it.

He looked across to the new hypermarket rising above the former playing fields and thought back to the lectures given by Mr Redbeard, Greyfriars' new politics lecturer, who said that the rot had set in with the removal of nutritional standards in school canteens in the 1980s and the introduction of competitive tendering.7 This allowed children to choose what they wanted to eat, in line with Conservative thinking on consumer choice. 7 The Black Report had even warned nearly 30 years ago that "to leave school children to make their own free choices of a meal ... would be likely to lead to "increases in obesity."8 Well, reflected Quelch, the turkey twizzlers had certainly come home to roost now. With an average of 23 junk food outlets per secondary school, promoting healthy eating was increasingly an uphill struggle.9 10

He examined his map of Greyfriars and its surroundings (fig 1).11 $\underline{\Downarrow}$ Greyfriars certainly showed no lack of green spaces, and the High Street Bun Shop was on the other side of Courtfield Common-hardly an obesogenic environment. Could the school tuck shop be to blame, then? It was right on the school 
premises after all ... perhaps he should have a look at what they were selling.12 There were so many potential influences on young people's diet, he reflected. "Portion distortion," for example, in which portion sizes are stealthily increased.13 14 Worse, in a vicious cycle, overweight children are more responsive to food promotion.15 So, concluded Quelch, the fatter Bunter gets, the more he responds to junk food adverts, which in turn makes him even fatter. Poor Bunter had become the junk food equivalent of a perpetual motion machine. Not everyone, however, believed obesity was a problem. There were denials by some in the food industry, 16 and even a class action against McDonalds on behalf of overweight children17 . . . it all sounded vaguely familiar, thought Quelch, as he filled his trusty briar with fragrant "Old Canker" shag and lit up.

Figure1

Greyfriars school and neighbourhood: not an obesogenic environment

Quelch's ruminations were interrupted as Bunter's father pulled up to Greyfriars' gates in the family SUV to take his stout progeny home for the weekend. Bunter's sister Bessie was also in the car, and she was no Kate Moss either, Quelch noticed.18 In fact, the whole Bunter family were strikingly similar, physically.11 Could obesity be genetic? He remembered Mr Venter's genetics lectures to the lower fourth. Yes, Greyfriars was in the clear, Quelch concluded. It's Bunter's genes that are at fault.19 And too much TV, of course.20 21 And all those fast food outlets.9 And the EU Common Agricultural Policy.22 And, possibly, Mr Bunter giving his son too much pocket money. Simple, really.

As he leaned out of his office window smoking his pipe he spotted the Fat Owl of the Remove in the tuck shop queue, waving a piece of paper. (Strange that the boy is still at Greyfriars, he mused. He seems rather old to still be at school.23)

"What's that, Bunter? Has your postal order arrived at last?"

"No sir, it's a cheque, from the Department of Health, Sir. They are paying overweight people to lose weight now. 2 If I keep my weight up, I might be able to make a few bob."

\section{Notes}

Cite this as: $B M J 2088 ; 337: a 2877$

\section{Footnotes}

- Funding: Monthly postal order from my employers, LSHTM.

- Competing interests: None declared.

\section{References}

1. Junk food banned in school meals. http://news.bbc.co.uk/1/hi/education/4995268.stm.

2. Healthy weight healthy lives. A cross-government strategy for England. London: Department of Health, January 2008.

3. Billy Bunter, the heavyweight chump of Greyfriars. Valiant Annual1976:20-21. London: IPC Magazines. 
4. Child weight letters obesity row. http://news.bbc.co.uk/1/hi/7541279.stm.

5. Foresight report: Tackling obesities: future choices. hwww.foresight.gov.uk/Obesity/17.pdf.

6. West $P$, Sweeting $H$, Young R. Smoking in Scottish youths: personal income, parental social class and the cost of smoking. Tobacco Control2007;16:329-35.

7. Gustafsson, U. School meals policy: the problem with governing children. Social Policy Administration 2002;36:685-97.

8. Inequalities in health: Report of a research working group (“The Black Report"). London: DHSS, 1980.

9. School Food Trust: New research reveals the scale of junk food temptation (28/03/08). www. schoolfoodtrust.org.uk/news item.asp?Newsld=127.

10. Macdonald L, Cummins S, Macintyre S. Appetite. Neighbourhood fast food environment and area deprivationsubstitution or concentration? Appetite 2007;49:251-4.

11. Butcher JS. Greyfriars School: a prospectus. Cassell, London, 1965:6-7.

12. Moore L, Tapper K. The impact of school fruit tuck shops and school food policies on children's fruit consumption: a cluster randomised trial of schools in deprived areas. J Epidemiol Community Health doi:10.1136/jech.2007.070953.

13. Schwartz J, Byrd-Bredbenner C. Portion distortion: typical portion sizes selected by young adults. J Am Dietetic Assoc2006;106:1412-8.

14. Food Standards Agency explores the role of portion sizes in our diet.

15. http://www.food.gov.uk/news/pressreleases/2008/jun/portionsize.

16. Halford JC, Boyland EJ, Hughes GM, Stavccey L, McKean S, Dovey TM. Beyond-brand effect of television (TV) food advertisements/commercials on caloric intake and food choice of 5-7-year-old children. Public Health Nutrition 2007;49:263-7.

17. Williams C. Does obesity carry too much weight? The Grocer 12 Jan, 2008:31.

18. Richards H. Bessie Bunter of Cliff House School. Charles Skilton, 1949

19. Carnell S, Haworth CM, Plomin R, Wardle J. Genetic influence on appetite in children. Int J Obesity2008;32:1468-73.

20. Chang PC, Li TC, Wu MT, Liu CS, Li Cl, Chen CC, et al. Association between television viewing and the risk of metabolic syndrome in a community-based population. BMC Public Health2008;8:193.

21. Miller SA, Taveras EM, Rifas-Shiman SL, Gillman MW. Association between television viewing and poor diet quality in young children. Int J Pediatric Obesity2008;4:1-9.

22. Hyde R. Europe battles with obesity. Lancet2008;3712:2160-1.

23. Billy Bunter 100 years old. Leatherhead Matters. 23 Feb 2008. http://leatherheadblog.com/2008/02/23/billybunter-100-years-old/. 